\title{
Telaah Literatur Potensi Lutein dari Bunga Marigold Lokal sebagai Suplemen Kesehatan
}

\section{Literature Review on the Potential of Lutein from Local Marigold Flowers as a Health Supplement}

\author{
Jovine Marcella Kurniawan ${ }^{1}$, Melisa Megawati Yusuf ${ }^{1}$, Heriyanto ${ }^{1,2}$, dan Tatas Hardo Panintingjati \\ Brotosudarmo ${ }^{1,2 *}$ \\ ${ }^{1}$ Program Studi Kimia, Fakultas Sains dan Teknologi, Universitas Ma Chung, Jln. Villa Puncak Tidar N-01 Malang, \\ Jawa Timur, Indonesia \\ ${ }^{2}$ Ma Chung Research Center for Photosynthetic Pigments, Universitas Ma Chung, Jln. Villa Puncak Tidar N-01 \\ Malang, Jawa Timur, Indonesia \\ *Korespondensi Penulis: tatas.brotosudarmo@machung.ac.id
}

Submitted: 27-02-2020, Revised: 02-07-2020, Accepted: 12-08-2020

DOI: https://doi.org/10.22435/mpk.v30i2.2874

\begin{abstract}
Abstrak
Lutein termasuk jenis xantofil yang terakumulasi secara dominan pada makula, serta terdistribusi pada beberapa bagian tubuh manusia seperti kulit dan otak. Akumulasi lutein pada tubuh manusia dikaitkan dengan manfaat kesehatan lutein, diantaranya sebagai antioksidan serta melindungi mata dan kulit dari paparan sinar biru, dan memainkan peranan penting untuk menjaga kesehatan kognitif manusia. Lutein tidak dapat disintesis oleh manusia, sehingga konsumsi lutein dapat diperoleh dari makanan seperti buah dan sayuran hijau, serta dari suplemen. Tujuan penulisan artikel ini adalah untuk meningkatkan kesadaran akan pentingnya kecukupan asupan lutein sejak dini dalam tubuh, serta menambah minat penelitian akan eksplorasi sumber daya lokal yang sebagai sumber potensial lutein yaitu bunga marigold Mega Orange dari Pulau Bali sebagai bahan baku suplemen kesehatan. Artikel potensi lutein sebagai suplemen kesehatan ini disusun dengan menelaah artikel-artikel pada jurnal internasional dan diikuti dengan pengujian komposisi karotenoid pada bunga marigold Mega Orange dan satu produk suplemen kesehatan dengan analisis Kromatografi Cair Kinerja Tinggi (KCKT). Berbagai penelitian dan publikasi artikel mengenai manfaat kesehatan lutein telah banyak ditemukan dalam dekade terakhir. Setidaknya terdapat dua manfaat utama lutein, yaitu sebagai antioksidan dan untuk menjaga kesehatan organ tubuh seperti mata, kulit, dan otak. Adapun, bunga marigold lokal varietas Mega Orange mengandung karotenoid lutein dan zeaksantin hingga $13,88 \mathrm{mg} / \mathrm{g}$ berat kering, dan hasil ini berada pada rentang konsentrasi lutein dalam bunga marigold yang tumbuh di Thailand. Bunga marigold Mega Orange merupakan sumber potensial lutein yang dapat digunakan sebagai bahan baku produk suplemen kesehatan. Pentingnya asupan lutein bagi tubuh manusia menjadikan pemanfaatan lutein dari bunga marigold lokal dalam pembuatan suplemen kesehatan perlu dioptimalkan dan dimanfaatkan.
\end{abstract}

Kata kunci: lutein; marigold; mata; otak; kulit; suplemen kesehatan.

\section{Abstract}

Lutein is a type of xanthophyll that accumulated predominantly in eye macula, and is distributed in several parts of the human body, such as skin and brain. Lutein accumulation in the human body is associated with the health benefits of lutein, including being an antioxidant and protecting, the eyes and skin from exposure to blue light, and playing an important role to maintain human cognitive health. Lutein cannot 
be synthesized by human, so consumption of lutein can be obtained from foods such as fruits and green vegetables, as well as from supplements. The purpose of writing this article was to increase awareness of the importance of adequate lutein intake early in the body, as well as increased research interest in exploring local resources as a potential source of lutein, the Mega Orange marigold from Bali as a raw material for health supplements. The potential lutein article as health supplement was prepared by reviewing articles from international journals and followed by testing the composition of carotenoids in Mega Orange marigolds and a health supplement product by HPLC analysis. Various studies and article publications regarding the health benefits of lutein have been found in the last decade. There are at least two main benefits of lutein, namely as an antioxidant and to maintain the health of organs such as the eyes, brain and skin. Meanwhile, the local marigold flower variety of Mega Orange contains carotenoids lutein and zeaxanthin up to $13.88 \mathrm{mg} / \mathrm{g}$ dry weight, and this result is in the range of lutein concentrations in marigold flowers that grow in Thailand. Mega Orange marigold is a potential source of lutein that can be used as raw materials for health supplement products. The importance of lutein intake for the human body makes the use of lutein from local marigolds in the manufacture of health supplements needs to be optimized and utilized.

Keywords: brain; eye; health supplement; lutein; marigold; skin

\section{PENDAHULUAN}

Lutein merupakan salah satu dari 750 jenis karotenoid yang sudah berhasil diidentifikasi di alam dan termasuk kedalam 25 jenis karotenoid yang ditemukan dalam serum dan bagian tubuh manusia. ${ }^{1}$ Bersama zeaksantin dan mesozeaksantin, lutein terdistribusi pada beberapa bagian mata dan terkonsentrasi dalam jumlah paling tinggi pada pusat makula, sehingga ketiga karotenoid tersebut dikenal sebagai pigmen makula (macular pigment). ${ }^{2,3}$ Lutein juga ditemukan pada kulit dan jaringan tubuh lainnya. ${ }^{4}$ Pada tahun 1992, Giuliano et $a l^{5}$ telah mengidentifikasi dan mengkuantifikasi lutein pada susu manusia. Penelitian terbaru oleh Johnson et al membuktikan bahwa lutein merupakan karotenoid dominan dalam jaringan otak manusia. Pada otak bayi yang baru lahir terkonsentrasi dua kali lebih tinggi dibandingkan dengan otak manusia dewasa. ${ }^{7}$ Keberadaan lutein dalam bagian tubuh manusia, yaitu mata, kulit, jaringan otak, dan bagian tubuh lainnya mengindikasikan peranan lutein bagi kesehatan manusia. Beberapa studi pustaka menunjukkan bahwa lutein memiliki efek yang positif bagi kesehatan manusia, antara lain adalah sebagai perlindungan terhadap paparan sinar atau cahaya biru (400-500 $\mathrm{nm}$ ) yang dapat merusak retina mata dan antioksidan, ${ }^{8}$ meningkatkan performa penglihatan, ${ }^{9}$ menurunkan risiko penyakit katarak, ${ }^{10}$ anti peradangan, ${ }^{11}$ menurunkan risiko penyakit age-related macular degeneration (AMD), meningkatkan kesehatan mata, ${ }^{12}$ meningkatkan kesehatan kulit, ${ }^{13}$ dan melindungi kulit dari sinar ultraviolet (UV), ${ }^{14}$ dan meningkatkan kesehatan bayi. ${ }^{15}$ Baru-baru ini ketertarikan terhadap lutein semakin meningkat karena peranannya dalam perkembangan otak dan meningkatkan fungsi otak. ${ }^{12,15}$

Akumulasi lutein dalam tubuh manusia sangat tergantung dari jenis asupan makanan dan pemberian suplemen lutein. Hal ini disebabkan karena karotenoid, termasuk lutein, tidak dapat dibiosintesis oleh manusia. Lutein dapat diperoleh dari makanan yang berwarna kuning sampai oranye, yaitu kuning telur dan jagung, serta sayuran berwarna hijau, misalnya bayam dan brokoli, ${ }^{16}$ namun beberapa sumber lutein tersebut mengandung lutein tidak dalam jumlah yang melimpah jika dibandingkan dengan bunga marigold. ${ }^{17}$ Penelitian terbaru yang dilakukan oleh Kurniawan et al menunjukkan kandungan karotenoid lutein dan zeaksantin dalam bunga marigold lokal Indonesia yaitu Mega Orange yang banyak dan mudah ditemukan di Tabanan, Pulau Bali, ${ }^{17}$ serta aplikasinya sebagai serbuk pewarna 
yang dienkapsulasi dalam matriks karbohidrat untuk pembuatan produk minuman fungsional. ${ }^{18}$ Hal ini juga dapat menunjukkan adanya peluang bagi Indonesia untuk memanfaatkan bunga marigold lokal varietas Mega Orange sebagai bahan aktif suplemen untuk kesehatan. Penulisan artikel ini diharapkan dapat meningkatkan kesadaran akan pentingnya kecukupan asupan lutein sejak dini dalam tubuh, serta menambah minat penelitian akan eksplorasi sumber daya lokal, khususnya bunga marigold Mega Orange sebagai bahan baku suplemen kesehatan lutein.

\section{METODE}

Analisis manfaat kesehatan lutein bagi tubuh manusia dilakukan dengan melakukan pencarian manfaat kesehatan lutein pada website resmi Science Direct (www.sciencedirect. com) dengan menuliskan kata kunci lutein dan manfaatnya untuk tubuh dalam Bahasa Inggris dalam rentang waktu 2010-2018. Kemudian dibuat grafik terkait dengan jumlah publikasi ilmiah manfaat kesehatan lutein terhadap fungsi tubuh masing-masing dari tahun 2010-2018 menggunakan Microsoft Excel. Sebanyak 519 paper penelitian mengenai manfaat kesehatan lutein telah ditemukan selama tahun 2010 hingga 2018 ditunjukkan pada Gambar 1.

Analisa kandungan karotenoid dalam ekstrak bunga marigold lokal Mega Orange dilakukan sesuai dengan Kurniawan et al. ${ }^{17}$ Hasil kandungan karotenoid dalam bunga marigold tersebut kemudian dibandingkan dengan satu suplemen kesehatan lutein yang dijual di pasaran. Adapun, penelusuran terkait berbagai suplemen lutein yang dijual di pasaran dilakukan dengan melakukan kunjungan ke toko suplemen dan obat di Malang, Jawa Timur, Indonesia.

\section{HASIL}

Terdapat 11 manfaat kesehatan lutein bagi tubuh manusia yang banyak diteliti (Gambar 1). Manfaat utama lutein bagi tubuh adalah sifatnya yang dapat bertindak sebagai antioksidan. Manfaat lainnya adalah sebagai antiinflamasi, antikanker, pemeliharaan kesehatan otak, mata, kulit, paruparu, dan kardiovaskular, meningkatkan sistem imun, hingga berpengaruh terhadap pertumbuhan dan perkembangan bayi yang baru lahir.

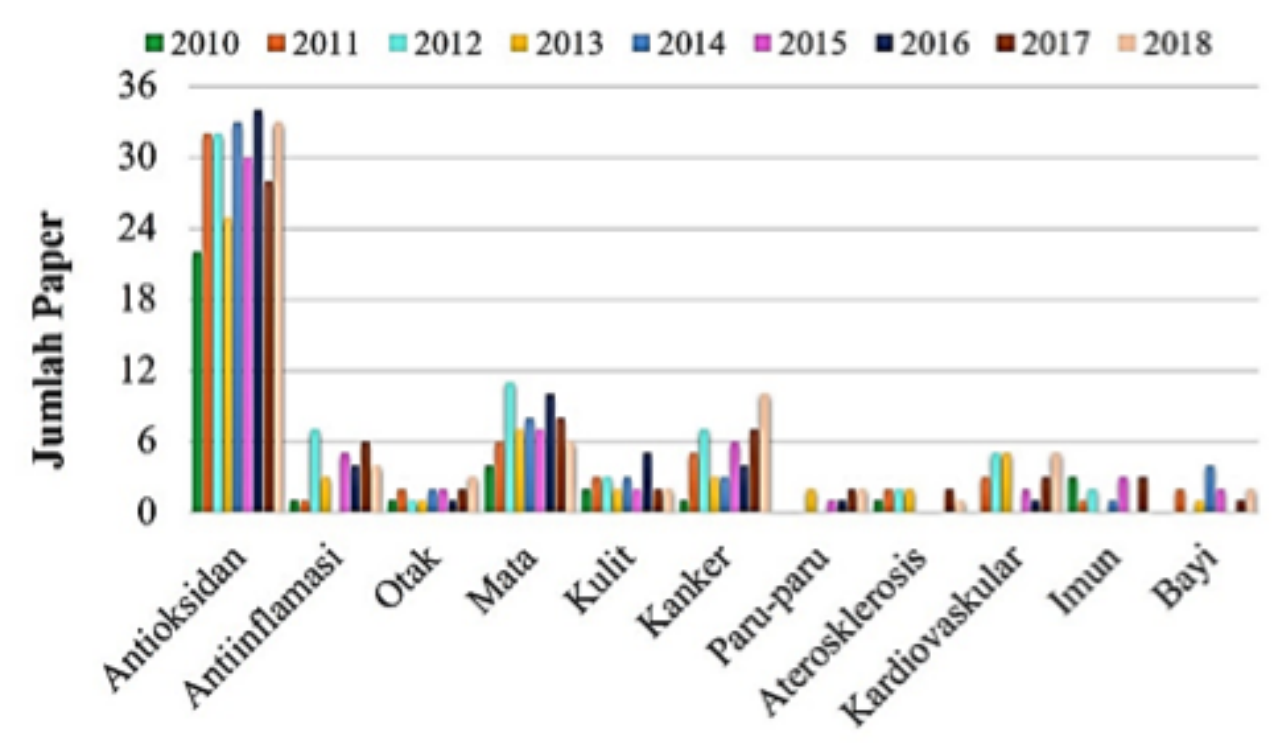

Fungsi Lutein

Gambar 1. Manfaat Kesehatan dan Fungsi Lutein dari 519 Paper yang dipublikasikan pada Jurnal, (Sumber: situs Science Direct) 
Pembahasan terkait manfaat lutein bagi tubuh akan dibahas selanjutnya pada bagian diskusi.

Suplemen kesehatan lutein untuk menjaga kesehatan mata, kulit, dan otak, maupun sebagai antioksidan telah banyak ditemukan, dan ditunjukkan pada Tabel 1. Suplemen lutein yang ditemukan diketahui mengandung kadar lutein yang berbeda-beda sesuai dengan kebutuhan tubuh berdasarkan informasi yang terdapat dalam label komposisi. Adapun, profil karotenoid dalam bunga marigold lokal varietas Mega Orange (sebelum dan sesudah saponifikasi) dan profil karotenoid yang terkandung dalam suplemen kesehatan lutein yang dianalisis dengan kromatografi cair kinerja tinggi (KCKT) ditunjukkan pada Gambar 2. Pada Gambar 2, pita biru menunjukkan hasil identifikasi komposisi karotenoid dalam salah satu suplemen kesehatan mata yang mengandung lutein dari ekstrak bunga marigold yang diproduksi oleh salah satu industri di Australia. Diketahui, suplemen tersebut mengandung lutein ester sebagai pigmen dominan. Selain itu, produk lutein ester NATChrom dari PT-PUI MRCPP Universitas Ma Chung yang didapatkan dari ekstrak bunga marigold lokal varietas Mega Orange memiliki komposisi dan kualitas yang sama dengan produk suplemen yang telah diuji (Gambar 2, pita merah).

Bunga marigold lokal varietas Mega Orange diketahui banyak sekali dan mudah ditemukan pada perkebunan bunga marigold di daerah Tabanan, Pulau Bali, Indonesia (Gambar 3). Selain itu, hasil penelitian menunjukkan bahwa bunga marigold lokal varietas Mega Orange mengandung lutein ester sebagai karotenoid dominan, dan setelah proses saponifikasi didapati kandungan lutein bebas sebesar $80 \%$ berdasarkan luas puncak lutein bebas pada analisa menggunakan KCKT (Gambar 2, pita hitam). ${ }^{17}$

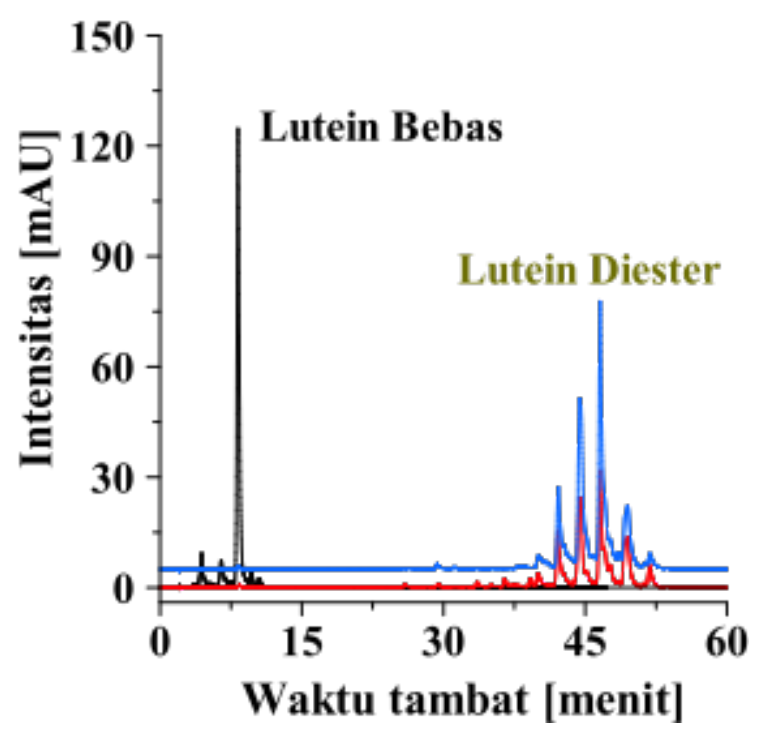

Gambar 2. Kromatogram KCKT Ekstrak Karatenoid Bunga Marigold Mega Orange Sebelum (Merah) dan Setelah Saponifikasi (Hitam) oleh NATChrom, dan Ekstrak Suplemen Lutein yang Dinormalisasi (Biru), Dideteksi pada $445 \mathrm{~nm}$
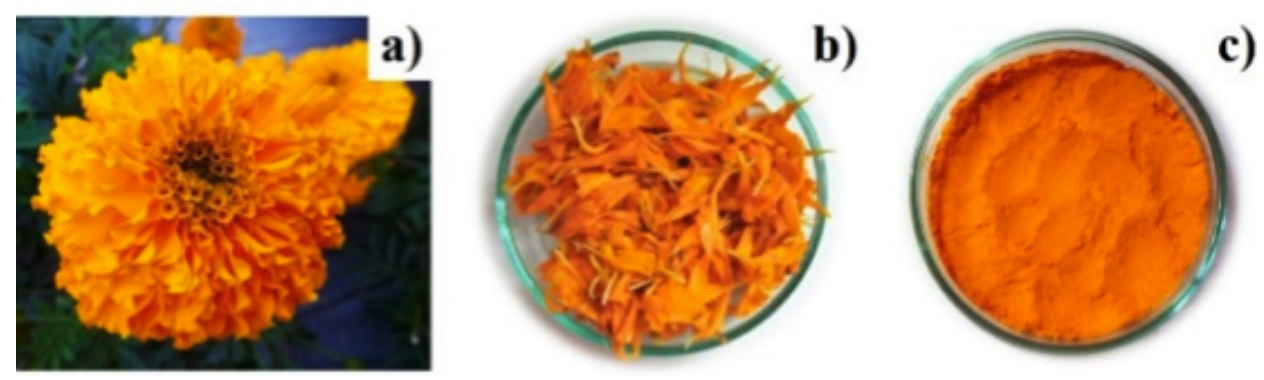

Gambar 3. Bunga Marigold Varietas Mega Orange (A), Kelopak (B), dan Serbuk (C) Bunga Marigold Mega Orange Hasil Pengeringan Menggunakan Freeze Dry 
Tabel 1. Produk Suplemen Kesehatan untuk Mata, Kulit, dan Otak yang Beredar di Pasaran Beserta Informasi Mengenai Kandungan Lutein (L), Zeaksantin (Z), dan Meso-Zeaksantin (MZ), serta Sumber Bahan Baku

\begin{tabular}{|c|c|c|c|c|c|}
\hline \multirow[t]{2}{*}{ Nama } & \multirow[t]{2}{*}{ Manufakturer } & \multicolumn{3}{|c|}{$\begin{array}{c}\text { Karotenoid } \\
\text { (mg/saji) }\end{array}$} & \multirow[t]{2}{*}{ Bahan Baku } \\
\hline & & $\mathbf{L}$ & $\mathbf{Z}$ & MZ & \\
\hline \multicolumn{6}{|l|}{ Untuk Mata } \\
\hline Lutein & Jarrow Formulas & 20 & 4 & - & Bunga Marigold \\
\hline Lutein & Rentless Improvement & 30 & 6 & - & Bunga Marigold \\
\hline Lutein Blue & Ahana Nutrition & 40 & - & - & Bunga Marigold \\
\hline Lutigold Extra & Puritan's Pride & & $20^{\text {a) }}$ & & Bunga Calendula \\
\hline Eye Protector & Pure Synergy & 10 & $5^{\mathrm{b})}$ & & Bunga Marigold \\
\hline \multicolumn{6}{|l|}{ Untuk Kulit, Kuku, dan Rambut } \\
\hline Biotin Plus & Natrol & 10 & - & - & Bunga Marigold \\
\hline Sunergetic & Sunergized & 6 & - & - & Bunga Marigold \\
\hline Skin, Hair \& Nails & Natrol & 10 & - & - & Bunga Marigold \\
\hline Marigold-Derived Lutein with Zeaxanthin & Zenwise & 20 & 1 & - & Bunga Marigold \\
\hline \multicolumn{6}{|l|}{ Untuk Otak } \\
\hline Prenatal & Frontrunners Health & 3 & - & - & Bunga Marigold \\
\hline Krill Oil Brain \& Vision Formula with Lutein & Daily Nutra & 12 & - & - & Bunga Marigold \\
\hline Lutein Plus Hx & InVite & 10 & 2 & - & Bunga Marigold \\
\hline Brain \& Vision Support & Puria & 10 & - & - & Bunga Marigold \\
\hline Super DHA plus Lutein & Carlson & 20 & 4 & - & Bunga Marigold \\
\hline
\end{tabular}

a) Total karotenoid L, Z, dan MZ; ${ }^{\text {b) }}$ total karotenoid Z dan MZ. Kandungan karotenoid diambil dari label komposisi produk suplemen kesehatan.

Tidak hanya itu, melalui penelitian ini diketahui bahwa bunga marigold lokal varietas Mega Orange yang dikeringkan dengan pengeringan beku (freeze drying) yang kemudian diserbukkan menjadi tepung (ukuran $<180 \mu \mathrm{m}$ ) mengandung karotenoid lutein dan zeaksantin hingga 13,9 $\mathrm{mg} / \mathrm{g}$ berat kering, dimana kandungan karotenoid ini berada pada rentang kandungan lutein dan zeaksantin pada bunga marigold yang tumbuh di Thailand $\left(8-20 \mathrm{mg} / \mathrm{g}\right.$ berat kering) ${ }^{19}$

\section{PEMBAHASAN \\ Struktur Kimia Lutein}

Senyawa lutein (rumus molekul $=\mathrm{C}_{40} \mathrm{H}_{56} \mathrm{O}_{2}$; massa molar $=568,87 \mathrm{~g} / \mathrm{mol}$ ) termasuk dalam golongan karotenoid yang memiliki 40 buah atom karbon dan 9 ikatan rangkap terkonjugasi pada rantai polienanya, serta memiliki dua gugus hidroksil pada cincin ionon sehingga tergolong sebagai xantofil - hidroksikarotenoid (Gambar 4). Adanya ikatan rangkap terkonjugasi pada 
struktur lutein membuat karotenoid ini mampu menyerap cahaya maupun menyerap kelebihan energi dari molekul lain sehingga dapat memiliki sifat antioksidan pula karena mampu menetralkan radikal bebas. ${ }^{20,21}$ Perbedaan senyawa lutein dan zeaksantin sebagai isomernya terletak pada posisi ikatan rangkap dua pada salah satu gugus hidroksil yang terikat pada cincin ionon. ${ }^{20}$ Adapun, gugus hidroksil pada senyawa lutein dan zeaksantin dipercaya memiliki peran penting pada fungsi biologis kedua karotenoid ini, dan memiliki peranan untuk mencegah pembelahan rantai poliena karotenoid ini dari reaksi oksidasi. 22,23

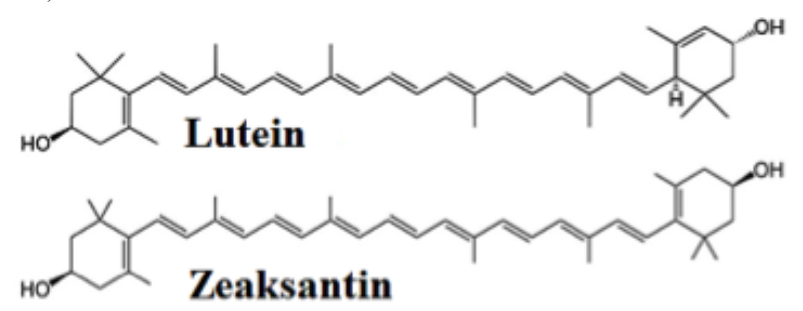

\section{Gambar 4. Struktur Molekul Lutein dan Zeaksantin}

Lutein berasal dari kata latin "Luteum" yang berarti kuning atau kuning telur, dimana dalam kondisi murni memiliki warna kuning hingga oranye bergantung dari konsentrasinya. Senyawa lutein pertama kali diisolasi dari korpus luteum manusia, merupakan pigmen yang tidak larut dalam air, namun bersifat sedikit lebih polar bila dibandingkan dengan karotenoid lainnya seperti likopen maupun beta-karoten ( $\beta$-karoten) karena adanya gugus hidroksil. ${ }^{24}$ Keberadaan gugus hidroksil pada senyawa lutein menjadikan xantofil ini tidak tergolong dalam karotenoid provitamin A (seperti alfa-karoten $(\alpha$-karoten $), \beta$-karoten, dan beta-kriptoksantin ( $\beta$-kriptoksantin). Hal ini disebabkan karena enzim spesifik tidak dapat memecah atau membelah ikatan antara karbon 15 dengan karbon 15' pada molekul lutein dan zeaksantin, sehingga senyawa vitamin A aldehida tidak terbentuk. ${ }^{24,25}$ Adapun struktur hidrokarbon dan keberadaan gugus hidroksil pada senyawa lutein diketahui mempengaruhi proses metabolisme senyawa lutein dalam tubuh hingga kemampuan penyerapan cahaya yang dihubungkan dengan penyimpanan dan stabilisasi lutein dalam jaringan tubuh. Selain itu, struktur senyawa lutein dipercaya memiliki orientasi potensial dalam membran lipid bilayer (sejajar dan tegak lurus) bila dibandingkan dengan karotenoid lainnya seperti zeaksantin (hanya tegak lurus) (Gambar 5). ${ }^{26}$

Lutein merupakan molekul yang mampu menyerap cahaya tampak pada daerah biru hingga ungu, sehingga membuat karotenoid ini merupakan filter ideal cahaya biru pada mata. ${ }^{27}$ Terkait dengan sifat lutein yang sedikit larut dalam air serta merupakan senyawa amfipatik, lutein dapat terakumulasi di dalam membran lipid bilayer ataupun berikatan dengan lipid..$^{28}$ Lutein dapat berada pada orientasi tegak lurus terhadap bidang membran lipid bilayer maupun sejajar dengan membran, dan hal ini akan mempengaruhi fluiditas membran, pertukaran ion, difusi oksigen hingga stabilitas membran itu sendiri. ${ }^{29}$ Senyawa lutein akan membentang di antara membran sel dengan rantai hidrokarbon (lipofilik) di dalam lipid bilayer, sedangkan gugus hidroksil (hidrofilik) akan mendorong konfigurasi membran yang membentang di lipid bilayer. Posisi orientasi karotenoid xantofil ini dapat mengoptimalkan kontak dengan membran lipid yang sangat teroksidasi (memainkan peranan antioksidan), serta juga meningkatkan stabilitas membran bilayer. Senyawa zeaksantin cenderung terdapat dalam posisi tegak lurus bidang membran. ${ }^{30}$

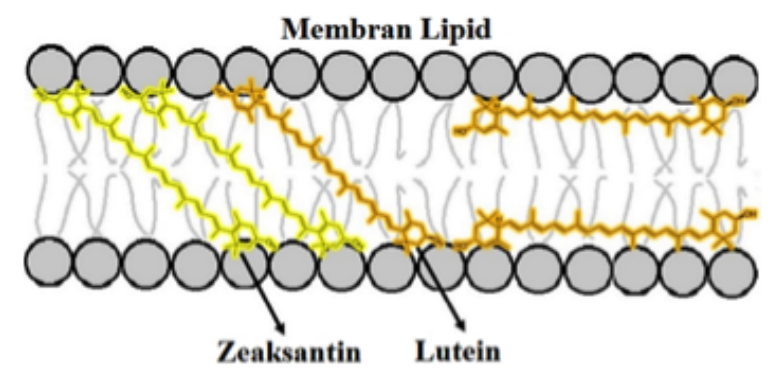

Gambar 5. Skema Lokasi Senyawa Xantofil Lutein (Oranye) dan Zeaksantin (Kuning) dalam Membran Lipid Bilayer ${ }^{30}$ 


\section{Keberadaan Lutein dalam Tubuh}

Lutein merupakan xantofil utama yang terdapat dalam serum dan darah manusia, bersama dengan beberapa karotenoid seperti $\alpha$-karoten dan $\beta$-karoten, serta likopen. ${ }^{31,32}$ Konsentrasi lutein dalam serum dan darah manusia bergantung pada konsumsi xantofil ini, serta faktor penyerapan xantofil pada jaringan tubuh. ${ }^{33}$ Selain pada serum dan darah, lutein terdapat dan tersebar pada beberapa jaringan tubuh manusia, seperti pada paru-paru $(0,1-2,3 \mu \mathrm{mol} / \mathrm{kg})$, ginjal $(0,1-10,4$ $\mu \mathrm{mol} / \mathrm{kg})$, kulit $(0,03 \mu \mathrm{mol} / \mathrm{kg})$, mukosa bukal $(4,45 \mu \mathrm{mol} / \mathrm{kg})$, dan terutama pada jaringan okular mata manusia atau retina $(1 \mathrm{mmol} / \mathrm{L}){ }^{8}$ Shegokar dan Mitri ${ }^{23}$ melaporkan bahwa lutein terdapat pada air susu ibu dalam rentang konsentrasi 3-200 $\mu \mathrm{g} / \mathrm{L}$, dan akan ditransferkan pada bayi yang dalam masa menyusui. Penelitian Wald $^{34}$ pertama kali melaporkan bahwa pigmen makula mengandung karotenoid, dimana lutein bersama-sama dengan zeaksantin dan mesozeaksantin terakumulasi pada makula mata, dimana konsentrasinya setara dengan akumulasi xantofil ini dalam tubuh, sehingga menjadikan lutein dan zeaksantin disebut sebagai pigmen makular. ${ }^{35}$

Proses transpor dan metabolisme dari senyawa lutein dalam tubuh serupa dengan senyawa lipofilik lainnya. Lutein yang dikonsumsi oleh manusia akan diserap pada usus manusia, kemudian ditransportasikan dari mukosa usus ke hepatosit. Lipoprotein densitas rendah dan lipoprotein densitas tinggi kemudian akan mentransportasikan lutein dari hepatosit menuju ke darah manusia. ${ }^{31}$ Pada buah-buahan dan kelopak bunga, umumnya lutein berikatan dengan ester atau asam lemak, hal ini membuat xantofil ester yang dikonsumsi oleh manusia perlu dihidrolisa oleh enzim lipase ataupun esterase pada usus manusia karena lutein yang akan didistribusikan dalam darah dan ke jaringan pada tubuh manusia harus berada dalam kondisi bebas atau tidak berikatan dengan asam lemak. ${ }^{37}$ Lutein dalam darah kemudian akan didistribusikan ke jaringan, organ dan serum, dan terutama akan terkonsentrasi pada retina dan makula mata. Terkonsentrasinya lutein serta zeaksantin pada mata manusia terkait dengan terlibatnya proses pengikatan lutein oleh senyawa StARD3 sebagai protein pengikat lutein dan GSTP1 (glutathione $S$-transferase) sebagai protein pengikat zeaksantin pada retina manusia (Gambar 6). ${ }^{28,38}$

Distribusi xantofil dalam mata menunjukkan bahwa perbedaan senyawa protein pengikat xantofil akan mempengaruhi akumulasi xantofil tersebut dalam mata, dimana lutein terakumulasi pada retina perifer dan diketahui berfungsi untuk melindungi sel batang sebagai fotoreseptor mata pada cahaya gelap, sedangkan zeaksantin terakumulasi pada retina pusat untuk melindungi sel kerucut sebagai fotoreseptor mata pada kondisi cahaya terang. ${ }^{38}$

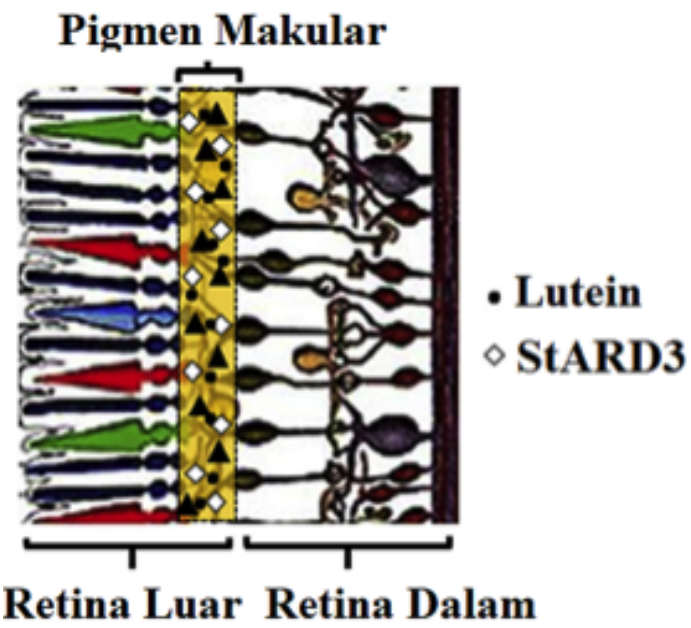

\section{Gambar 6. Ilustrasi Akumulasi dan Pengikatan Lutein oleh StARD3 sebagai Protein Pengikat Lutein pada Retina Mata ${ }^{28,38}$}

\section{Sumber Lutein}

Karena lutein terdapat dan terdistribusi pada berbagai jaringan dan organ manusia serta memiliki berbagai manfaat, keberadaan lutein dalam tubuh manusia menjadi penting. Lutein merupakan karotenoid yang hanya dapat disintesis oleh organisme fotosintetik seperti tumbuhan, makro- dan mikro-alga maupun bakteri, sehingga kebutuhan asupan lutein dalam 
tubuh dapat diperoleh dari konsumsi sayuran hijau maupun buah-buahan. ${ }^{39,40}$ Makanan yang mengandung lutein dan zeaksantin ditunjukkan pada Gambar 7. Selain mengkonsumsi sumber makanan tersebut, lutein dapat diperoleh dalam jumlah yang banyak melalui asupan suplemen dengan memanfaatkan sumber daya hayati lokal Indonesia, yaitu dari bunga marigold. Lutein yang terkandung dalam bunga marigold memiliki konsentrasi pada rentang 1,61-20,59 mg/g berat kering ${ }^{19-41}$ sekitar 100 kali lebih tinggi bila dibandingkan dengan kandungan karotenoid ini dalam kale atau sayur kubis.

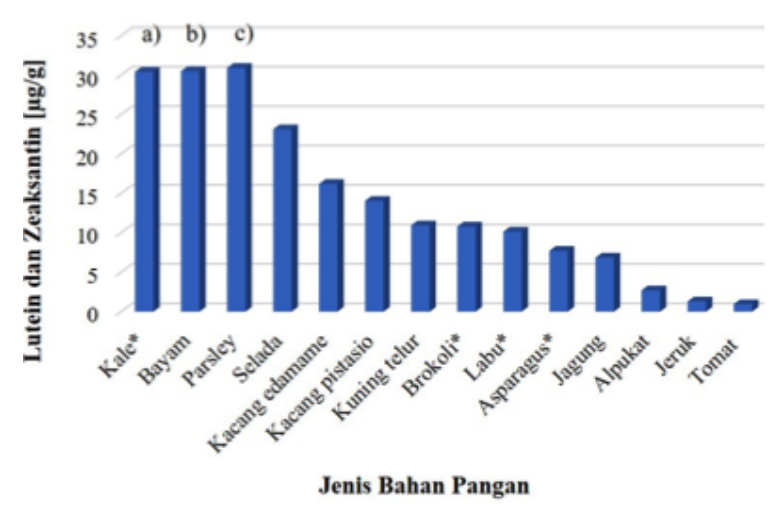

Gambar 7. Kandungan Karotenoid Lutein Dan Zeaksantin dalam Bahan Pangan; *)

Bahan Pangan dalam Kondisi Matang; A) Nilai Kandungan Dibagi 6; B) Nilai Kandungan Dibagi dengan 4; C) Nilai Kandungan Dibagi dengan 1,8

\section{Manfaat Lutein}

\section{Manfaat Lutein untuk Mata}

Lutein merupakan karotenoid yang terakumulasi secara dominan pada mata, khususnya pada makula dan retina manusia. ${ }^{8,21}$ Makula merupakan pusat penglihatan manusia yang terletak pada kutub posterior retina yang berperan dalam ketajaman visual dan kemampuan membedakan warna. ${ }^{43}$ Pigmen makular tersusun atas tiga senyawa karotenoid yaitu lutein, zeaksantin, dan meso-zeaksantin dengan konsentrasi 1000 kali lipat lebih tinggi dibandingkan dalam darah. ${ }^{21,43}$ Senyawa lutein secara dominan terakumulasi pada makula mata manusia pada umur kurang dari dua tahun, dan

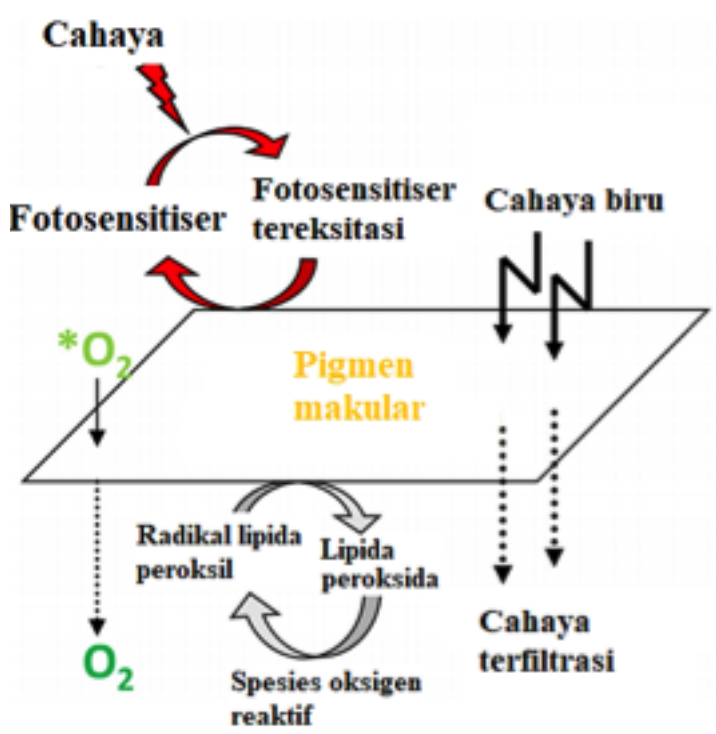

\section{Gambar 8. Fungsi Pigmen Makular sebagai Antioksidan pada Mata ${ }^{8}$}

setelah dua tahun akumulasi pigmen zeaksantin dan meso-zeaksantin akan semakin meningkat. ${ }^{36}$ Lutein, zeaksantin, dan meso-zeaksantin memiliki peran penting dalam melindungi retina dan pigmen makular dari kerusakan oksidatif akibat cahaya dengan meredam spesies oksigen reaktif dan bertindak sebagai agen filter sinar biru..$^{20,43,44}$ Paparan sinar biru dapat direduksi hingga $40 \%$ oleh pigmen makular terkait dengan serapan pigmen makular pada daerah biru (400-500 $\mathrm{nm}$ ), sehingga mampu mereduksi sinar biru yang masuk ke dalam retina. ${ }^{13,44}$ Selain itu, lutein yang terlarut dalam membran fosfolipid tidak jenuh ganda berperan melawan peroksidasi lemak pada jaringan retina yang sebagian besar tersusun atas asam lemak tidak jenuh ganda (seperti DHA) yang rentan terhadap kerusakan oksidatif saat terpapar oksigen pada konsentrasi yang tinggi. ${ }^{8,21}$

Katarak dan penyakit degenerasi makula merupakan penyebab utama kebutaan pada orang lanjut usia. ${ }^{20}$ Paparan okular terhadap cahaya matahari dan sinar UV secara intens dapat menyebabkan penyakit katarak dan degenerasi retina melalui reaksi fotooksidasi. Pada reaksi fotooksidasi, kromofor fototoksik pada mata akan menyerap cahaya dan berubah ke dalam keadaan yang tidak stabil (keadaan singlet menjadi triplet) kemudian akan menggenerasi senyawa 
membentuk radikal bebas atau oksigen menjadi oksigen singlet. Lutein dapat bertindak sebagai antioksidan dengan mencegah kerusakan akibat reaksi fototoksik dengan menyerap dan mencegah kerusakan retina akibat cahaya dan meredam oksigen singlet pada retina selama kondisi stres oksidatif. $^{21,44,45}$ Ilustrasi fungsi pigmen makular sebagai antioksidan pada mata ditunjukkan pada Gambar 8 .

\section{Degerasi Makula}

Beberapa penyakit yang berkaitan dengan degenerasi makula seperti katarak, retinitis pigmentosa, retinopati diabetik, hiperlipidemia, hiperkolestrolemia, dan ateroskeloris dapat terjadi akibat stres oksidatif maupun pembentukan spesies oksigen reaktif. ${ }^{44}$ Penyakit degenerasi makula terkait usia (AMD) merupakan penyebab utama gangguan penglihatan dan kebutaan pada orang yang berusia 65 tahun ke atas. ${ }^{46} \mathrm{Hal}$ ini disebabkan oleh penurunan sistem antioksidan alami dan peningkatan produksi spesies oksigen reaktif oleh kromofor endogen fototoksik yang menyerap sinar UV dan sinar tampak sehingga mampu menyebabkan kerusakan sel. ${ }^{21,47}$ Lutein dapat menetralkan perubahan akibat stres pada epitel pigmen retina dengan memperbaiki sambungan antarsel dan menekan inflamasi dengan meredam dan induksi enzim endogen antioksidan..$^{21}$

\section{Katarak}

Katarak merupakan kekeruhan degeneratif pada lensa mata yang dapat menyebabkan hilangnya penglihatan secara parsial maupun keseluruhan. Sebesar 50\% penyebab kebutaan dan $33 \%$ gangguan penglihatan disebabkan oleh katarak. Gejala yang dapat muncul adalah penglihatan yang buram, warna yang terlihat memudar, serta gangguan penglihatan saat siang dan malam hari. Protein lensa yang teroksidasi dan tidak terlarut akibat stres oksidatif merupakan

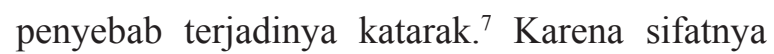
sebagai antioksidan, lutein dipercaya memiliki peran mencegah stres oksidatif dan mengurangi risiko terkena penyakit katarak dan penyakit degeneratif lainnya. ${ }^{48,49}$ Lutein dapat melindungi mata dari katarak senilis dengan mempengaruhi perubahan oksidasi glutation, yang bertanggung jawab dalam meningkatnya kerentanan inti terhadap kerusakan oksidatif pada lensa yang telah tua. ${ }^{21}$

\section{Manfaat Lutein untuk Otak}

Aktivitas antioksidan senyawa lutein dikaitkandengankemampuannyadalammencegah terjadinya oksidasi membran lipid, khususnya pada jaringan fotoreseptor yang kaya akan asam lemak tak jenuh ganda, serta menstabilkan radikal bebas melalui proses peredaman oksigen singlet secara fisika. ${ }^{15,21}$ Retina mata dan otak manusia diketahui saling berhubungan, di mana informasi visual yang diterima melalui mata akan diinterpretasikan oleh otak dengan melibatkan saraf optik, sehingga dapat dikatakan bahwa retina mata merupakan bagian dari otak. ${ }^{50}$ Retina mata dan jaringan otak diketahui terhubung oleh sistem saraf khususnya jaringan saraf pusat, ${ }^{15,51}$ dan keduanya tersusun dari asam lemak tak jenuh ganda dan memiliki aktivitas metabolik yang tinggi sehingga rentan terhadap stres oksidatif akibat radikal bebas. ${ }^{52}$ Keberadaan lutein dalam jaringan mata dapat diukur melalui nilai densitas optikal pigmen makular, dimana nilai ini juga terkorelasi dengan akumulasi lutein dalam otak dan diketahui berkaitan dengan fungsi otak seperti kemampuan dan kelancaran berbicara, kemampuan memproses sinyal dan menanggapi sinyal dengan cepat bagi orang lanjut usia. ${ }^{21}$

Lutein merupakan karotenoid dominan dalam jaringan otak manusia, ${ }^{6}$ dan pada otak bayi yang baru lahir terkonsentrasi dua kali lebih tinggi dibandingkan dengan otak manusia dewasa. ${ }^{7}$ Vishwanathan et $a^{53}$ melakukan penelitian terkait dengan kandungan karotenoid pada otak bayi yang meninggal pada tahun pertama kelahiran, dan diketahui bahwa terdapat akumulasi beberapa karotenoid secara signifikan, seperti lutein (58\%), zeaksantin (19\%), kriptoksantin (8\%) 
dan $\beta$-karoten (15\%), serta sedikit likopen (3\%). Asupan karotenoid ini pada otak diperkirakan memiliki fungsi penting dalam pengembangan sistem saraf sejak dini. ${ }^{7,50}$ Akumulasi senyawa lutein pada daerah otak tertentu (prefrontal cortex, striatum, dan hipokampus) serta membran tertentu (mitokondria, membran plasma neuron, mielin) akan mempengaruhi fungsi dan peran lutein (Tabel 1). ${ }^{15}$

Lutein memiliki fungsi sebagai neuroprotektif, hal ini dikaitkan dengan karakteristik dan posisi lutein yang unik dalam membran sel. Aksi lutein sebagai neuroprotektif dikaitkan dengan keberadaannya yang terlokalisasi pada membran otak yang kaya akan kandungan asam lemak tak jenuh ganda seperti asam lemak omega- 3 atau docohexaenoic acid (DHA) dan arachidonic acid (AA), yang rentan terhadap stres oksidatif. ${ }^{15,54}$ Keberadaan lutein pada membran otak dapat mencegah oksidasi lipid. Tidak hanya itu, aksi lutein dalam mencegah oksidasi lipid akan dapat memelihara lemak tak jenuh ganda rantai panjang seperti DHA, sehingga struktur membran dan fluiditas terjaga, dan menjaga kadar DHA dalam otak hingga akhirnya dapat dipecah, dikonversi dan dimanfaatkan sebagai senyawa anti-peradangan yang diperlukan oleh otak. ${ }^{15,55}$ Lutein sebagai senyawa yang polar dan mudah larut dalam membran sehingga akan mempengaruhi fluiditas, komunikasi antar neuron melalui gap junction, pertukaran ion, difusi oksigen, stabilitas membran, hingga mencegah oksidasi dan inflamasi. ${ }^{12,15,26}$

Terkait dengan manfaat kesehatan lutein pada otak, penelitian terkini dilakukan untuk mengindentifikasi hubungan antara lutein dengan penyakit degeneratif saraf seperti alzeimer yang menyebabkan penurunan kemampuan kognitif serta parkinson. Aksi proteksi lutein terhadap saraf otak terkait dengan penyakit degeneratif saraf tersebut adalah dengan melindungi neuron dopaminergik dan membran mitokondria dari kerusakan, serta sebagai antioksidan dan anti apoptotik. Adanya lutein mampu menghambat aktivasi senyawa proapoptotik (bax dan kapase) serta meningkatkan produksi senyawa antiapoptotik (Bcl-2) pada saraf otak. ${ }^{56}$

\section{Manfaat Lutein untuk Kulit}

Kulit manusia merupakan bagian tubuh yang paling terpapar cahaya matahari, polusi, serta mungkin terpapar senyawa-senyawa kimia lain. Paparan sinar UV berlebih pada kulit dapat menginduksi pembentukan senyawa radikal seperti oksigen singlet dapat menyebabkan terjadinya stres oksidatif, inflamasi, hingga pembentukan sel kanker pada kulit. ${ }^{57,58}$ Tidak hanya itu, paparan sinar UV dapat menyebabkan kulit terbakar dan kerusakan sel epidermal dan dermal kulit. ${ }^{59}$

Radiasi sinar UV/A (320-400 nm) merupakan sumber utama (95\%) penyebab stres oksidatif pada kulit dan terserap pada lapisan sel kulit dermis, sedangkan paparan radiasi sinar UV/B (290-320 nm) merupakan sumber utama penyebab penyakit kanker nonmelanoma, dan paparan sinar ini secara berlebih dapat menurunkan sistem imun dan peradangan pada sel kulit. ${ }^{60}$ Senyawa lutein diketahui terakumulasi pada kulit manusia, bersama dengan beberapa xantofil lain seperti zeaksantin, $\alpha$ - dan $\beta$-kriptoksantin, ${ }^{61}$ dan bertindak sebagai antioksidan dengan meredam senyawa oksigen singlet dan senyawa radikal bebas lain. Lutein pada kulit juga berperan sebagai fotoprotektor yang dapat menyerap sinar biru sehingga dapat melindungi kulit dari bahaya sinar UV dan sinar tampak (Gambar 9). ${ }^{62}$

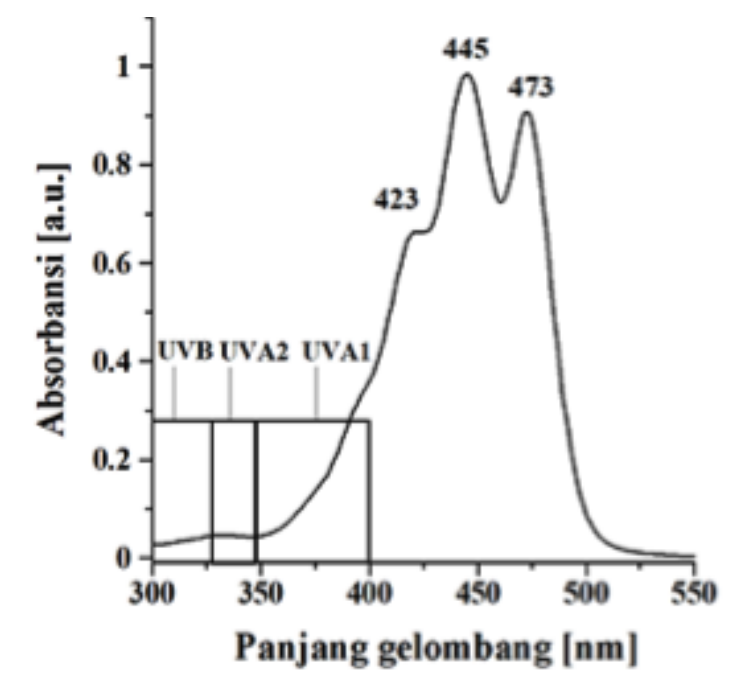

Gambar 9. Spektrum Serapan Lutein dan Rentang Serapan Sinar UV/A dan UV/B 
Tabel 1. Peran Lutein dalam Berbagai Bagian dan Sel Otak ${ }^{15}$

\begin{tabular}{|c|c|c|}
\hline Lokasi & Fungsi & Peran Lutein \\
\hline Prefrontal cortex & $\begin{array}{l}\text { Mengkontrol kemampuan kognitif otak terkait dengan } \\
\text { perencanaan dan pengambilan keputusan, pemecahan } \\
\text { masalah, fleksibilitas dan kemampuan berbahasa. }\end{array}$ & \multirow{3}{*}{$\begin{array}{l}\text { Meningkatkan kerja dan kognitif } \\
\text { otak, serta mengontrol memori otak. }\end{array}$} \\
\hline Striatum & $\begin{array}{l}\text { Mengkontrol motivasi, memori, serta perhatian selama } \\
\text { bekerja. }\end{array}$ & \\
\hline Hipokampus & $\begin{array}{l}\text { Pembentukkan dan konsolidasi memori atau kenangan yang } \\
\text { telah terjadi, serta mengkontrol memori spasial. }\end{array}$ & \\
\hline $\begin{array}{l}\text { Membran plasma } \\
\text { neuron }\end{array}$ & $\begin{array}{l}\text { Berperan dalam kelangsungan hidup sel, memodulasi } \\
\text { aksesibilitas antar membran reseptor, hingga menentukan } \\
\text { viabilitas sel melalui proses signaling. }\end{array}$ & $\begin{array}{l}\text { Mempegaruhi sinyal transduksi dari } \\
\text { sel hidup. }\end{array}$ \\
\hline Mitokondria & $\begin{array}{l}\text { Produksi senyawa ATP, menghasilkan senyawa oksigen } \\
\text { singlet yang reaktif sebagai produk samping. }\end{array}$ & $\begin{array}{l}\text { Mencegah kerusakan membran } \\
\text { mitokondria akibat penumpukkan } \\
\text { oksigen singlet dan stres oksidatif } \\
\text { yang dapat membuat produksi ATP } \\
\text { menjadi kurang efisien. }\end{array}$ \\
\hline Selubung Mielin & $\begin{array}{l}\text { Membungkus akson, meningkatkan kecepatan transfer } \\
\text { impuls saraf, sangat penting bagi efisiensi komunikasi antar } \\
\text { neuron. }\end{array}$ & $\begin{array}{l}\text { Mempengaruhi struktur mielin, serta } \\
\text { menjaga komunikasi antar neuron } \\
\text { agar tidak terjadi gangguan berpikir } \\
\text { dan mengingat. }\end{array}$ \\
\hline
\end{tabular}

Karena lutein merupakan golongan xantofil utama dengan aktivitas antioksidan yang tinggi pada sel kulit, maka konsumsi lutein dapat membantu mencegah beberapa penyakit dan kerusakan oksidatif kulit (seperti edema dan hiperplasia), mengurangi terbentuknya eritema (inflamasi), mengurangi tingkat peroksidasi lipid pada kulit, ${ }^{13,47}$ dan mampu mencerahkan warna kulit. ${ }^{47}$ Hal ini disebabkan karena peredaman radikal bebas dan penyerapan sinar warna biru oleh lutein yang dapat menghambat pembentukan melanin (eumelanin dan feomelanin) yang berkontribusi pada warna gelap pada kulit. Selain itu, bila dibandingkan dengan karotenoid lain ( $\beta$-karoten dan likopen), lutein dan zeaksantin merupakan golongan xantofil yang paling resisten terhadap degradasi akibat stres oksidatif. ${ }^{47}$

\section{Lutein sebagai Suplemen Kesehatan}

Melalui hasil studi pustaka terkait dengan manfaat lutein bagi kesehatan manusia, sifat antioksidan diketahui merupakan manfaat yang terutama. Jumlah publikasi lutein sebagai antioksidan pada website Science Direct paling banyak jumlahnya, diikuti dengan manfaat lutein untuk anti peradangan, menjaga kesehatan mata, kulit, dan otak, dan pencegahan kanker. Adapun, telah dijabarkan pada subbab sebelumnya terkait dengan manfaat kesehatan lutein bagi mata, kulit, dan otak manusia, senyawa lutein dipercaya mampu menjaga kesehatan mata, kulit, dan otak manusia karena tidak lepas dari sifatnya sebagai antioksidan alami.

Konsumsi lutein pada bagian tubuh tertentu bergantung pada penyerapan sel dalam tubuh, dan antara bagian yang satu dan yang lain akan berbeda jumlahnya. ${ }^{23,37}$ Untuk menjaga kesehatan mata dan otak, lutein ester dapat dikonsumsi dengan konsentrasi 12-40 mg/hari, ${ }^{37,63}$ sedangkan untuk menjaga kesehatan kulit dan memanfaatkan lutein sebagai antioksidan, lutein ester dapat dikonsumsi hingga $6 \mathrm{mg} /$ hari. $^{37}$ Adapun baik lutein maupun lutein ester tidak bersifat toksik dan aman dikonsumsi hingga 30-40 mg/hari, ${ }^{64}$ dan bagi bayi yang mengonsumsi susu yang diperkaya lutein aman hingga $250 \mu \mathrm{g} / \mathrm{L} .{ }^{65}$ 
Bunga marigold merupakan bahan baku potensial lutein, ${ }^{66-68}$ dimana sebagian besar suplemen lutein yang ditemui menggunakan lutein ester dari ekstrak bunga marigold. ${ }^{19,69}$ Proses hidrolisis basa menggunakan pelarut etanol yang mengandung kalium hidroksida dapat memutuskan ikatan antara lutein dan ester asam lemak sehingga dapat dihasilkan lutein bebas, ${ }^{70}$ namun perlu diperhatikan bioavailabilitas dan kestabilan lutein ketika diaplikasikan pada berbagai bidang, khususnya dalam pembuatan suplemen. ${ }^{67}$ Pemanfaatan bunga marigold varietas lokal dapat menjadi alternatif dalam mengembangkan suplemen kesehatan lutein, yang mampu bersaing dengan suplemen kesehatan lain dari luar negeri.

\section{KESIMPULAN}

Lutein merupakan xantofil yang terakumulasi pada mata, kulit, otak dan berbagai bagian tubuh manusia. Keberadaan lutein dalam tubuh memiliki banyak manfaat kesehatan bagi manusia, dan bertindak sebagai antioksidan dan agen filtrasi cahaya biru. Bunga marigold lokal varietas Mega Orange merupakan sumber potensial lutein. Adapun, pentingnya asupan lutein bagi tubuh manusia menjadikan pemanfaatan lutein dari bunga marigold lokal dalam pembuatan suplemen kesehatan perlu dioptimalkan dan dimanfaatkan.

\section{UCAPAN TERIMA KASIH}

Penulis mengucapkan terima kasih atas dukungan dari Kementerian Riset, Teknologi, dan Pendidikan Tinggi, Direktorat Jenderal Penguatan Riset dan Pengembangan, melalui SINAS (25/INS-2/PPK/E4/2018). Selain itu ucapan terima kasih juga diberikan kepada PT. Mitra Ayu Adi Pratama (www.ptmitraayu.com) untuk dukungannya atas sediaan konsentrat lutein ester dari bunga marigold Mega Orange sebagai bahan baku penelitian.

\section{DAFTAR PUSTAKA}

1. Bernstein PS, Khachik F, Carvalho LS, Muir GJ, Zhao DY, Katz NB. Identification and quantitation of carotenoids and their metabolites in the tissues of the human eye. Exp Eye Res. 2001;72(3):21523.

2. Schalch W, Landrum JT, Bone RA. The Eye. In: Britton G, Pfander H, Liaaen-Jensen S, editors. Carotenoids Volume 5: Nutrition and Health. Birkhäuser Basel; 2009. p. 301-34.

3. Bone RA, Landrum JT, Tarsis SL. Preliminary identification of the human macular pigment. Vision Res. 1985;25(11):1531-5.

4. Nierenberg DW, Nann SL. A method for determining concentrations of retinol, tocopherol, and five carotenoids in human plasma and tissue samples. Am J Clin Nutr. 1992;56:417-26.

5. Giuliano AR, Neilson EM, Kelly BE, Canfield LM. Simultaneous quantitation and separation of carotenoids and retinol in human milk by highperformance liquid chromatography. Methods Enzymol. 1992;213:391-9.

6. Johnson EJ, Vishwanathan R, Johnson MA, Hausman DB, Davey A, Scott TM, et al. Relationship between serum and brain carotenoids, a -tocopherol, and retinol concentrations and cognitive performance in the oldest old from the georgia centenarian study. J Aging Res. 2013;2013:951786.

7. Hirdyani H, Sheth M. Lutein - the Less explored carotenoid. World J Pharm Res. 2017;6(6):52853.

8. Kijlstra A, Tian Y, Kelly ER, Berendschot TTJM. Lutein: More than just a filter for blue light. Prog Retin Eye Res [Internet]. 2012;31(4):303-15. Available from: http://dx.doi.org/10.1016/j. preteyeres.2012.03.002

9. Nolan JM, Loughman J, Akkali MC, Stack J, Scanlon G, Davison P, et al. The impact of macular pigment augmentation on visual performance in normal subjects: COMPASS. Vision Res [Internet]. 2011;51:459-69. Available from: http://dx.doi.org/10.1016/j.visres.2010.12.016 
10. Christen WG, Liu S, Glynn RJ, Gaziano JM, Buring JE. Dietary carotenoids, vitamins $\mathrm{C}$ and $\mathrm{E}$, and risk of cataract in women: A prospective study. Arch Ophthalmol. 2008;126(1):102-9.

11. Chung RWS, Leanderson P, Lundberg AK, Jonasson L. Lutein exerts anti-inflammatory effects in patients with coronary artery disease. Atherosclerosis [Internet]. 2017;262:87-93. Available from: http://dx.doi.org/10.1016/j. atherosclerosis.2017.05.008

12. Johnson EJ. Role of lutein and zeaxanthin in visual and cognitive function throughout the lifespan. Nutr Rev. 2014;72(9):605-12.

13. Roberts RL, Green J, Lewis B. Lutein and zeaxanthin in eye and skin health. Clin Dermatol [Internet]. 2009;27:195-201. Available from: http://dx.doi.org/10.1016/j. clindermatol.2008.01.011

14. Grether-Beck S, Marini A, Jaenicke T, Stahl W, Krutmann J. Molecular evidence that oral supplementation with lycopene or lutein protects human skin against ultraviolet radiation: results from a double-blinded, placebocontrolled, crossover study. Br J Dermatol. 2017;176(5):1231-40.

15. Erdman J, Smith J, Kuchan M, Mohn E, Johnson E, Rubakhin S, et al. Lutein and brain function. Foods. 2015;4(4):547-64.

16. Sommerburg O, Keunen JEE, Bird AC, van Kuijk FJGM. Fruits and vegetables that are sources for lutein and zeaxanthin: The macular pigment in human eyes. $\mathrm{Br} \mathrm{J}$ Ophthalmol [Internet]. 1998;82(8):907-10. Available from: http://0-ovidsp.ovid.com.wam.city.ac.uk/ ovidweb.cgi?T $=\mathrm{JS} \& \mathrm{PAGE}=$ reference $\& \mathrm{D}=$ emed4\&NEWS $=$ N\&AN $=1998300000$

17. Kurniawan JM, Yusuf MM, Azmi SS, Salim KP, Utami Prihastyanti MN, Indrawati R, et al. Effect of drying treatments on the contents of lutein and zeaxanthin in orange- and yellow-cultivars of marigold flower and its application for lutein ester encapsulation. IOP Conf Ser Mater Sci Eng. 2019;509:012060.
18. Indrawati R, Kurniawan JM, Wibowo AA, Juliana, Gunawan IA, Heriyanto, et al. Integrated solvent-free extraction and encapsulation of lutein from marigold petals and its application. CYTA - J Food [Internet]. 2019;17(1):121-7. Available from: https://doi.org/10.1080/1947633 7.2018 .1544591

19. Ingkasupart P, Manochai B, Song WT, Hong JH. Antioxidant activities and lutein content of 11 marigold cultivars (Tagetes spp.) grown in Thailand. Food Sci Technol. 2015;35(2):380-5.

20. Namitha KK, Negi PS. Chemistry and biotechnology of carotenoids. Crit Rev Food Sci Nutr. 2010;50(8):728-60.

21. Perrone S, Tei M, Longini M, Buonocore G. The multiple facets of lutein: A call for further investigation in the perinatal period. Oxid Med Cell Longev. 2016;2016:5381540.

22. Johnson EJ. The role of carotenoids in human health. Nutr Clin Care. 2002;5(2):56-65.

23. Shegokar R, Mitri K. Carotenoid lutein: A promising candidate for pharmaceutical and nutraceutical applications. J Diet Suppl. 2012;9(3):183-210.

24. Ma L, Lin XM. Effects of lutein and zeaxanthin on aspects of eye health. J Sci Food Agric. 2010;90(1):2-12.

25. Mares-Perlman JA, Millen AE, Ficek TL, Hankinson SE. The body of evidence to support a protective pole for lutein and zeaxanthin in delaying chronic disease. Overview. J Nutr. 2002;132:518S-524S.

26. Krinsky NI. Possible biologic mechanisms for a protective role of xanthophylls. J Nutr. 2002;132(March):540-2.

27. Krinsky NI, Landrum JT, Bone RA. Biologic mechanisms of the protective role of lutein and zeaxanthin in the eye. Annu Rev Nutr. 2003;23(1):171-201. 
28. Bernstein PS, Li B, Vachali PP, Gorusupudi A, Shyam R, Henriksen BS, et al. Lutein, zeaxanthin, and meso-zeaxanthin: The basic and clinical science underlying carotenoid-based nutritional interventions against ocular disease. Prog Retin Eye Res. 2016;50:34-66.

29. Widomska J, Subczynski WK. Why has nature chosen lutein and zeaxanthin to protect the retina? J Clin Exp Ophthalmol. 2014;5:326.

30. Sujak A, Gabrielska J, Grudziński W, Borc R, Mazurek P, Gruszecki WI. Lutein and zeaxanthin as protectors of lipid membranes against oxidative damage: The structural aspects. Arch Biochem Biophys. 1999;371:301-7.

31. Parker RS. Carotenoids in human blood and tissues. J Nutr. 1989;119:101-4.

32. Stimpson JP, Urrutia-Rojas X. Acculturation in the United States is associated with lower serum carotenoid levels: Third national health and nutrition examination survey. J Am Diet Assoc. 2007;107(7):1218-23.

33. Johnson EJ, Hammond BR, Yeum KJ, Qin J, Wang XD, Castaneda C, et al. Relation among serum and tissue concentrations of lutein and zeaxanthin and macular pigment density. Am J Clin Nutr. 2000;71:1555-62.

34. Wald G. Human vision and the spectrum. Science (80- ). 1945;101(2635):653-8.

35. Bone RA, Landrum JT, Friedes LM, Gomez CM, Kilburn MD, Menendez E, et al. Distribution of lutein and zeaxanthin stereoisomers in the human retina. Exp Eye Res. 1997;64(2):211-8.

36. Bone RA, Landrum JT, Fernandez L, Tarsis SL. Analysis of the macular pigment by HPLC: Retinal distribution and age study. Investig Ophthalmol Vis Sci. 1988;29(6):843-9.

37. Alves-Rodrigues A, Shao A. The science behind lutein. Toxicol Lett. 2004;150:57-83.

38. Sommerburg O, Siems WG, Hurst JS, Lewis JW, Kliger DS, Van Kuijk FJGM. Lutein and zeaxanthin are associated with photoreceptors in the human retina. Curr Eye Res. 1999;19:491-5.
39. Holden JM, Eldridge AL, Beecher GR, Marilyn Buzzard I, Bhagwat S, Davis CS, et al. Carotenoid Content of U.S. Foods: An Update of the Database. J Food Compos Anal. 1999;12:169-96.

40. Nwachukwu ID, Udenigwe CC, Aluko RE. Lutein and zeaxanthin: Production technology, bioavailability, mechanisms of action, visual function, and health claim status. Trends Food Sci Technol [Internet]. 2016;49:74-84. Available from: http://dx.doi.org/10.1016/j.tifs.2015.12.005

41. Li W, Gao Y, Zhao J, Qi W. Phenolic, flavonoid, and lutein ester content and antioxidant activity of 11 cultivars of Chinese marigold. J Agric Food Chem. 2007;55(21):8478-84.

42. Eisenhauer B, Natoli S, Liew G, Flood VM. Lutein and zeaxanthin - Food sources, bioavailability and dietary variety in age $\square$ related macular degeneration protection. Nutrients. 2017;9(2):120.

43. Ma L, Liu R, Du JH, Liu T, Wu SS, Liu XH. Lutein, zeaxanthin and meso-zeaxanthin supplementation associated with macular pigment optical density. Nutrients. 2016;8:426.

44. Carpentier S, Knaus M, Suh M. Associations between lutein, zeaxanthin, and age-related macular degeneration: An overview. Crit Rev Food Sci Nutr. 2009;49(4):313-26.

45. Kamoshita M, Toda E, Osada H, Narimatsu T, Kobayashi S, Tsubota K, et al. Lutein acts via multiple antioxidant pathways in the photostressed retina. Sci Rep. 2016;6:30226.

46. Ferris FL. Senile macular degeneration: Review of epidemiologic features. Am J Epidemiol. 1983;118(2):132-51.

47. Juturu V, Bowman JP, Deshpande J. Overall skin tone and skin-lightening-improving effects with oral supplementation of lutein and zeaxanthin isomers: A double-blind, placebo-controlled clinical trial. Clin Cosmet Investig Dermatol. 2016;9:325-32.

48. Koushan K, Rusovici R, Li W, Ferguson LR, Chalam K V. The role of lutein in eye-related disease. Nutrients. 2013;5:1823-39. 
49. Vu HTV, Robman L, Hodge A, McCarty CA, Taylor HR. Lutein and zeaxanthin and the risk of cataract: The Melbourne visual impairment project. Investig Ophthalmol Vis Sci. 2006; 47:3783-6.

50. Juturu V. Lutein, brain, and neurological functions. In: Watson R, Preedy V, editors. Bioactive Nutraceuticals and Dietary Supplements in Neurological and Brain Disease: Prevention and Therapy. 1st editio. Academic Press; 2015. p. 41-7.

51. London A, Benhar I, Schwartz M. The retina as a window to the brain - From eye research to CNS disorders. Nat Rev Neurol [Internet]. 2013;9(1):44-53. Available from: http://dx.doi. org/10.1038/nrneurol.2012.227

52. Johnson EJ. A possible role for lutein and zeaxanthin in cognitive function in the elderly. Am J Clin Nutr. 2012;96:1161S-5S.

53. Vishwanathan R, Kuchan MJ, Johnson EJ, Mayer J, Hnrca U, St W. Lutein is the predominant carotenoid in the infant brain. In: 16th International Symposium on Carotenoids. Krakow; 2011.

54. Mohn ES, Erdman JW, Kuchan MJ, Neuringer M, Johnson J. Lutein accumulates in subcellular membranes of brain regions in adult rhesus macaques: Relationship to DHA oxidation products. PLoS One. 2017;12(10):e0186767.

55. Miller E, Morel A, Saso L, Saluk J. Isoprostanes and neuroprostanes as biomarkers of oxidative stress in neurodegenerative diseases. Oxid Med Cell Longev. 2014;2014:572491.

56. Nataraj J, Manivasagam T, Justin A, Essa MM. Lutein protects dopaminergic neurons against MPTP-induced apoptotic death and motor dysfunction by ameliorating mitochondrial disruption and oxidative stress. Nutr Neurosci [Internet]. 2016;19(6):237-46. Available from: http://dx.doi.org/10.1179/147683051 5Y.0000000010

57. Hruza LL, Pentland AP. Mechanisms of UVinduced inflaimnation. J Invest Dermatol. 1993;100(1):35S-42S.

58. Black S. Potential involvement of free radical reactions in ultraviolet light-mediated cutaneous damage. Photochem Photobiol. 1987;46(2):21321.
59. Lopes DM, Mcmahon SB. Ultraviolet radiation on the skin : A painful experience ? CNS Neurosci Ther. 2016;22:118-26.

60. Lee EH, Faulhaber ÃD, Hanson KM, Ding W, Peters S, Kodali S, et al. Dietary lutein reduces ultraviolet radiation-induced inflammation and immunosuppression. J Invest Dermatol. 2004;122(2):510-7.

61. Wingerath T, Sies H, Stahl W. Xanthophyll esters in human skin. Arch Biochem Biophys. 1998;355(2):271-4.

62. González S, Astner S, An W, Goukassian DA, Pathak MA. Dietary lutein/zeaxanthin decreases ultravioletB-inducedepidermalhyperproliferation and acute inflammation in hairless mice. J Invest Dermatol. 2003;121(2):399-405.

63. Johnson EJ, Mcdonald K, Caldarella SM, Chung H, Troen AM, Snodderly DM. Cognitive findings of an exploratory trial of docosahexaenoic acid and lutein supple- mentation in older women. Nutr Neurosci. 2008;11(2):75-84.

64. Landrum JT, Bone RA, Joa H, Kilburn MD, Moore LL, Sprague K. A one year study of the macular pigment: the effect of 140 days of a lutein supplement. Exp Eye Res. 1997;65(1):57-62.

65. Bresson J-L, Flynn A, Heinonen M, Hulshof K, Korhonen H, Lagiou P, et al. Safety , bioavailability and suitability of lutein for the particular nutritional Scientific Opinion of the Panel on Dietetic Products, Nutrition and Allergies. Eur Food Saf Auth J. 2008;823:1-24.

66. Priyanka D, Shalini T, Navneet VK. A brief study of marigold (Tagetes species): A review. Int Res J Pharm. 2013;4(1):43-8.

67. Hadden WL, Watkins RH, Levy LW, Regalado E, Rivadeneira DM, Breemen RB Van, et al. Carotenoid composition of marigold ( Tagetes erecta) flower extract used as nutritional supplement. J Agric Food Chem. 1999;47(10):4189-94.

68. Tinoi J, Rakariyatham N, Deming RL. Determination of major carotenoid constituents in petal extracts of eight selected flowering plants in the North of Thailand. Chiang Mai J Sci. 2006;33(2):327-34. 
69. Piccaglia R, Marotti M, Grandi S. Lutein and lutein ester content in different types of Tagetes patula and T . erecta. Ind Crops Prod. 1998;8(1):45-51.

70. Boonnoun P, Tunyasitikun P, Clowutimon W, Shotipruk A. Production of free lutein by simultaneous extraction and de-esterification of marigold flowers in liquefied dimethyl ether (DME)-KOH-EtOH mixture. Food Bioprod Process Trans Inst Chem Eng Part C [Internet]. 2017;106:193-200. Available from: http:// dx.doi.g/10.1016/j.fbp.2017.10.002 